\title{
TrkB antibody elicits cytotoxicity and suppresses migration/invasion of transitional cell carcinoma cells
}

\author{
YEN TA HUANG ${ }^{1,2,3,4}$, PEI CHUN LAI ${ }^{1,5}$, CHIA CHEN WU ${ }^{6}$, CHUAN CHU CHENG ${ }^{6}$ and TED H. CHIU ${ }^{1,7}$ \\ ${ }^{1}$ Institute of Pharmacology and Toxicology, ${ }^{7}$ Department of Pharmacology, Tzu Chi University; \\ ${ }^{2}$ Division of Surgical Critical Care Unit, ${ }^{3}$ Department of Emergency Medicine, ${ }^{4}$ Division of Nephrology, \\ ${ }^{5}$ Department of Pediatrics, ${ }^{6}$ Department of Research, Buddhist Tzu Chi General Hospital, Hualien 970, Taiwan, R.O.C.
}

Received April 29, 2010; Accepted June 2, 2010

DOI: 10.3892/ijo_00000745

\begin{abstract}
BDNF (brain-derived neurotrophic factor) and its receptor TrkB (tropomyosin receptor kinase B) play important roles in the progression of cancer, including transitional cell carcinoma (TCC) cells reported in our previous investigation. In this study, we used a specific TrkB antibody $(\mathrm{Ab})$ to evaluate its effects on survival, proliferation and migration/ invasion in three TCC cell lines (BFTC905, T24 and TSGH8301) in vitro. The TrkB Ab at 1 and $3 \mu \mathrm{g} / \mathrm{ml}$, but not the TrkA or TrkC Abs, significantly elicited cytotoxicity in TCC cells. The TrkB Ab at $3 \mu \mathrm{g} / \mathrm{ml}$ also induced apoptosis of TCC cells, which may result from up-regulation of phosphop38 plus down-regulation of survivin and securin expression. The TrkB Ab at $0.5 \mu \mathrm{g} / \mathrm{ml}$, which did not show cytotoxicity, suppressed migration of TCC cells and invasion of BFTC905 cells, possibly mediated through increased E-cadherin, decreased BDNF-stimulated phospho-PLC $\gamma 1$ and reduced MMP-9 activity. These results indicate that TrkB blockade may be a new strategy for TCC therapy.
\end{abstract}

\section{Introduction}

Trk (tropomyosin receptor kinase) family of tyrosine kinase receptors consists of TrkA, TrkB and TrkC. Each Trk is activated by its preferred neurotrophin ligands, e.g., NGF (nerve growth factor) binds to TrkA, BDNF (brain-derived neurotrophic factor) and NT4/5 (neurotrophin 4/5) bind to TrkB, and NT3 binds to TrkC. These Trk receptors and their ligands play important roles in neuronal survival and differentiation (1).

Apart from neuronal functions, Trk receptors also possess oncogenic character $(2,3)$. Some cancer cells have been reported to express Trk receptors (4). For example, BDNF

Correspondence to: Dr Ted H. Chiu, Institute of Pharmacology and Toxicology, Tzu Chi University, Hualien, 970 Taiwan, R.O.C. E-mail: uncleda.huang@gmail.com

Key words: brain-derived neurotrophic factor, tropomyosin receptor kinase $\mathrm{B}$, bladder cancer, transitional cell carcinoma protects neuroblastoma cells from chemotherapeutic agent induced cytotoxicity (5). However, high level of TrkA expression in neuroblastoma specimens is associated with favorable outcome (6). Trk receptors may be potential targets for cancer therapy, but specific Trk blockade has only been investigated in few studies (7). Our previous study demonstrated the existence of BDNF and TrkB in transitional cell carcinoma (TCC) cell lines (8). BDNF and TrkB are overexpressed in human TCC specimens compared to normal urothelium (unpublished results). TrkB activation mediated by BDNF is a survival signal for TCC (8). Therefore, we hypothesize that selective TrkB blockade may be exploited as an alternative new treatment for TCC cells. Our results demonstrate that TrkB antibody inhibits proliferation, and migration/invasion, and induces apoptosis in TCC cells.

\section{Materials and methods}

Cell culture. Three human TCC cell lines including BFTC905, TSGH8301 and T24 were chosen for the investigation. The cells were maintained as described previously (8). Gradings of BFTC905 (9) and TSGH8301 (10), both originated from Taiwanese TCC patients, T24 from ATCC (American Type Culture Collection, Manassas, VA) are 3 and 2, and 2/3, respectively.

Cell proliferation and MTT cytotoxicity assay. TCC cells were plated at a density of $8 \times 10^{4}$ cells in 6-well dishes with RPMI medium containing $10 \%$ FBS. The plating day was designated as day 1 . One or $3 \mu \mathrm{g} / \mathrm{ml}$ of TrkB antibody (Ab) (sc-8316, Santa Cruz Biotechnology Inc., Santa Cruz, CA), $3 \mu \mathrm{g} / \mathrm{ml}$ of human IgG (Sigma, St. Louis, MO), or PBS was added separately to the culture dishes on day 2. Calculation of the cell counts in a hemocytometer was performed on day 5 ( $72 \mathrm{~h}$ after TrkB Ab administration).

For cytotoxicity assay, TCC cells with $1 \times 10^{4}$ cells per well were seeded in 96-well plates. Time designation was the same as cell growth assay. Different concentrations (1 or $3 \mu \mathrm{g} / \mathrm{ml}$ ) of TrkA Ab (AF175, R\&D Systems, Minneapolis, MN), TrkB Ab (sc-8316, Santa Cruz), or TrkC Ab (AF373, R\&D Systems) were administered on day 2. Human IgG treatment served as a negative control. Conventional MTT (methylthiazolyldiphenyl-tetrazolium bromide, Sigma) assay followed $72 \mathrm{~h}$ (day 5) after $\mathrm{Ab}$ administration (8). 
A
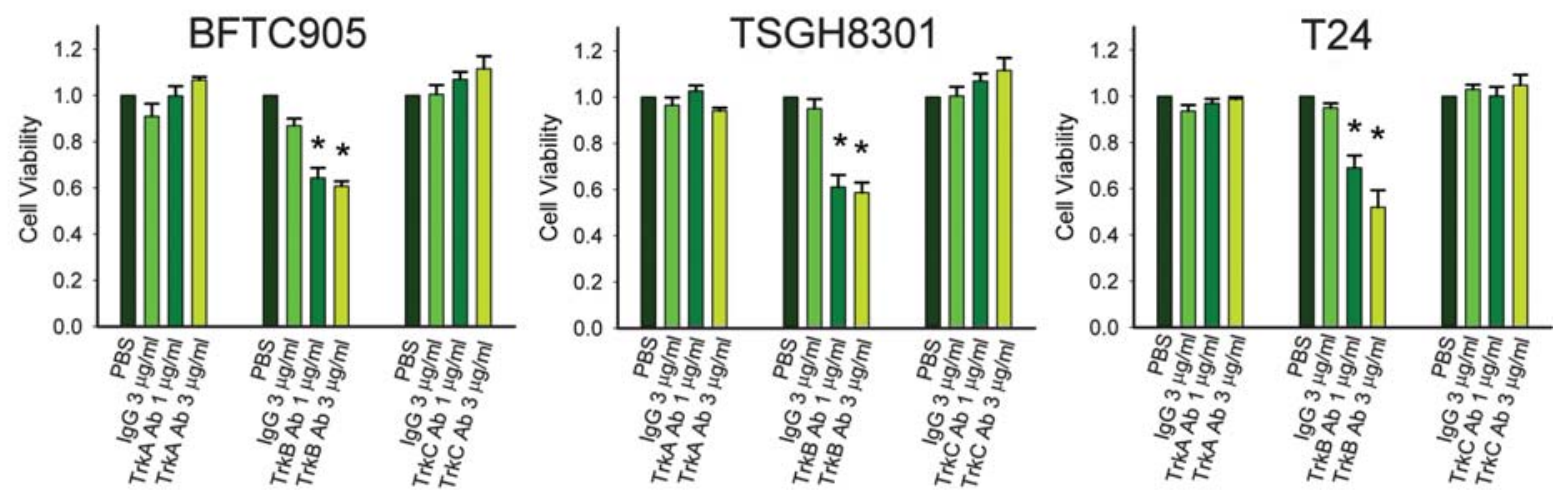

B
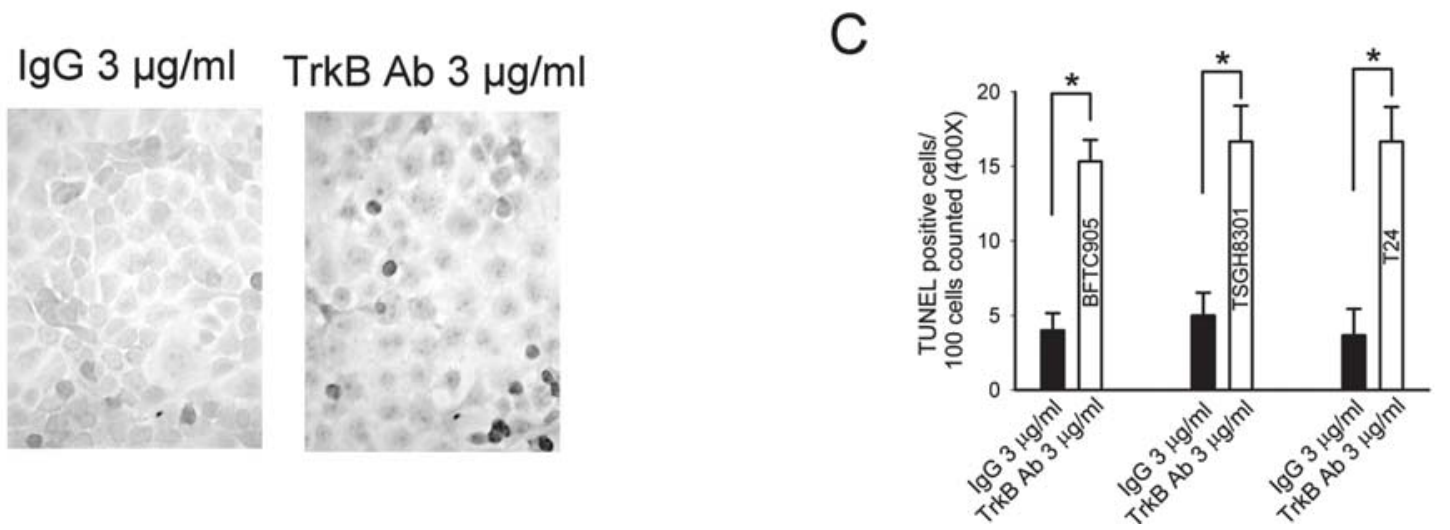

Figure 1. Cytotoxicity of Trk Ab in TCC cells. (A) Viabilities of TCC cells were measured by MTT assay $72 \mathrm{~h}$ after TrkA, TrkB, or TrkC Ab treatment. The viability ratio was calculated as the ratio of O.D. value from Ab treatment divided by that of PBS. TrkB Ab elicited significant cytotoxicity on 3 TCC cell lines with concentration of $1 \mu \mathrm{g} / \mathrm{ml}(0.64 \pm 0.04,0.61 \pm 0.05$ and $0.69 \pm 0.05$ for BFTC905, TSGH8301 and T24, respectively; $\mathrm{n}=3-4)$ and $3 \mu \mathrm{g} / \mathrm{ml}(0.61 \pm 0.02$, $0.59 \pm 0.04$ and $0.52 \pm 0.07$ for BFTC905, TSGH8301 and T24, respectively; n=3-4). (B) Apoptotic BFTC905 cells were detected by the TUNEL assay. Dark staining of nuclei indicated DNA fragmentation of cells after $3 \mu \mathrm{g} / \mathrm{ml}$ of TrkB Ab or IgG treatment for $24 \mathrm{~h}$ (x400). (C) Significantly increased TUNELpositive cells were observed after TrkB Ab treatments compared to IgG treatments (BFTC905, TSGH8301 and T24; left to right).

Western blot. Standard procedures were followed (8). Primary antibodies used included anti-phospho-p38 (no. 9211, Cell Signaling, Danvers, MA), anti-p38 (sc-535, Santa Cruz), anti-phospho-PLC $\gamma 1$ (no. 2821, Cell Signaling), anti-PLC $\gamma 1$ (no. 2822, Cell Signaling), E-cadherin (sc-7870, Santa Cruz), anti-survivin (GF029, Millipore, Billerica, MA), and antisecurin (ab3305, Abcam, Cambridge, MA). Expression of ERK2 (sc-154, Santa Cruz), or actin (sc-1616, Santa Cruz) was used as the internal standard. Can Get Signal ${ }^{\mathrm{TM}}$ immunostain was used for enhancement of phosphorylated protein signals (Toyobo, Osaka, Japan). The intensity of immunoreactive proteins was calculated with NIH software ImageJ V.1.40.

TUNEL (terminal deoxynucleotidyl transferase dUTP nick end-labeling) assay. The TACS-XL ${ }^{\text {тм }}$ in situ apoptosis kit (R\&D Systems) was used for the detection of DNA fragmentation of TCC cells. Cells were treated with $3 \mu \mathrm{g} / \mathrm{ml}$ of IgG or TrkB Ab for $24 \mathrm{~h}$ and fixed with $4 \%$ paraformalde-hyde for $10 \mathrm{~min}$. Subsequent procedures suggested by the assay kit were followed. Cells were chosen randomly from 10 fields and photographed under x400 light microscopy for semiquantitation. The number of positive nuclear stain indicating
DNA fragmentation and thus apoptosis was counted. The ratio of apoptotic cells divided by total cells in a chosen field was calculated, and the data were expressed as numbers of apoptotic cells per 100 cells counted.

Invasion/migration assay. Wound healing assay was used for the migration study. BFTC905, T24 and TSGH8301 cells were cultured separately in 3-cm dishes in an RPMI medium containing $0.5 \%$ FBS. Several straight wounds were established by the tip of a $2-\mu 1$ pipette on the dish filled with cancer cells. TrkB Ab at 0.1 or $0.5 \mu \mathrm{g} / \mathrm{ml}$, or human IgG at $0.5 \mu \mathrm{g} / \mathrm{ml}$ were delivered into the medium on the day of wound development. After $24 \mathrm{~h}$, cells were stained with hematoxylin and the wounds were observed and photographed under x40 magnification.

The BioCoat ${ }^{\mathrm{TM}}$ growth factor reduced Matrigel ${ }^{\mathrm{TM}}$ Invasion Chamber (BD Biosciences, MA) was used for in vitro invasion study. TCC cells $\left(2.5 \times 10^{4}\right)$ in $500 \mu 1$ of a medium containing $1 \%$ FBS were delivered to the chamber. TrkB Ab $(0.5 \mu \mathrm{g} / \mathrm{ml})$ was added to the chamber, and $\operatorname{IgG}(0.5 \mu \mathrm{g} / \mathrm{ml})$ served as control. Subsequently, the chambers were put into 24-well plate containing $750 \mu 1$ of culture medium plus $10 \%$ FBS. After 48-h incubation, invading cells on the bottom 
surface of the membrane were counted under microscope. Cell numbers per field in both chambers (x200) counted from 10 randomized fields by two staff members were averaged.

MMP-9 activity assay. Matrix metalloproteinase-9 (MMP-9) activity in culture medium was measured by ELISA method (Biotrak activity assay system, code RPN2634, Amersham Pharmacia Biotech, Little Chalfont, UK). TrkB Ab at $0.5 \mu \mathrm{g} / \mathrm{ml}$ was added to $1 \times 10^{6}$ BFTC905 cells cultured in 24-well dishes with serum-free medium. After $24 \mathrm{~h}$, MMP-9 activity in the medium was assayed according to manufacturer's instructions.

Statistical analysis. Data are presented as mean \pm SEM (standard error of mean). The difference between experimental and control group was evaluated by Student's t-test. In all experiments, $\mathrm{p}<0.05$ was considered statistically significant and labeled by the symbol * in the figures.

\section{Results}

TrkB Ab elicited cytotoxicity and suppressed the proliferation of TCC cells. Cytotoxicity was measured by MTT assay $72 \mathrm{~h}$ after TrkA, TrkB, or TrkC Ab treatment. As shown in Fig. 1A, only TrkB Ab (both 1 and $3 \mu \mathrm{g} / \mathrm{ml}$ for 3 TCC cell lines) exerted significant toxicity on TCC cells while TrkA Ab, TrkC Ab, and IgG was without cytotoxic effects. Fig. 1B shows that more TUNEL-positive BFTC905 cells were observed after $3 \mu \mathrm{g} / \mathrm{ml}$ TrkB Ab when compared to IgG treatment. Apoptotic TCC cells were increased significantly $24 \mathrm{~h}$ after $3 \mu \mathrm{g} / \mathrm{ml}$ TrkB Ab treatment (4.0 \pm 1.2 vs. 15.3 \pm 1.5 , $5.0 \pm 1.5$ vs. $16.7 \pm 2.4$, and $3.6 \pm 1.8$ vs. $16.7 \pm 2.3$ for BFTC 905 , TSGH8301 and T24 cells after IgG vs. TrkB Ab treatment, respectively; n=3) (Fig. 1C). Furthermore, proliferation of TCC cells was significantly suppressed $72 \mathrm{~h}$ after administration of $3 \mu \mathrm{g} / \mathrm{ml}$ TrkB Ab $(53.3 \pm 6.1$ vs. $24.0 \pm 4.5,61.0 \pm 2.8$ vs. $34.0 \pm 4.0,90.6 \pm 1.6$ vs. $47.0 \pm 7.4 \times 10^{4}$ in BFTC905, TSGH8301 and T24 cells after PBS vs. TrkB Ab treatment, respectively; $n=3$ ) (Fig. 2). No differences in cell numbers among PBS, IgG and $1 \mu \mathrm{g} / \mathrm{ml}$ TrkB Ab treatments were observed.

TrkB Ab induced phospho-P38, and inhibited survivin and securin expression in TCC cells. The effect of TrkB Ab on the expression of phospho-p38 mitogen-activated protein kinase (MAPK) was examined because activation of $\mathrm{p} 38$ by several chemotherapeutic agents has been reported to mediate cancer cells apoptosis (11). After the addition of $3 \mu \mathrm{g} / \mathrm{ml}$ of TrkB Ab to TCC cells, a time-dependent increase in phospho-p38 expression was found (Fig. 3A). The increased expression was obvious as early as $2 \mathrm{~h}$ post-treatment, the earliest time studied, and continued to increase for $24 \mathrm{~h}$. The intensity ratio of phospho-p38/total p38 was increased from zero (in the absence of treatment) to $\sim 2$ after $24 \mathrm{~h}$ treatment (Fig. 3B).

Survivin, a member of the inhibitor of apoptosis protein family, has been shown to be a promising biomarker for diagnosis and prognosis of bladder cancer. Decreased expression of survivin in bladder cancer specimens has been reported to be a good prediction of response to therapies $(12,13)$. As shown in Fig. 3C and D, expression of survivin
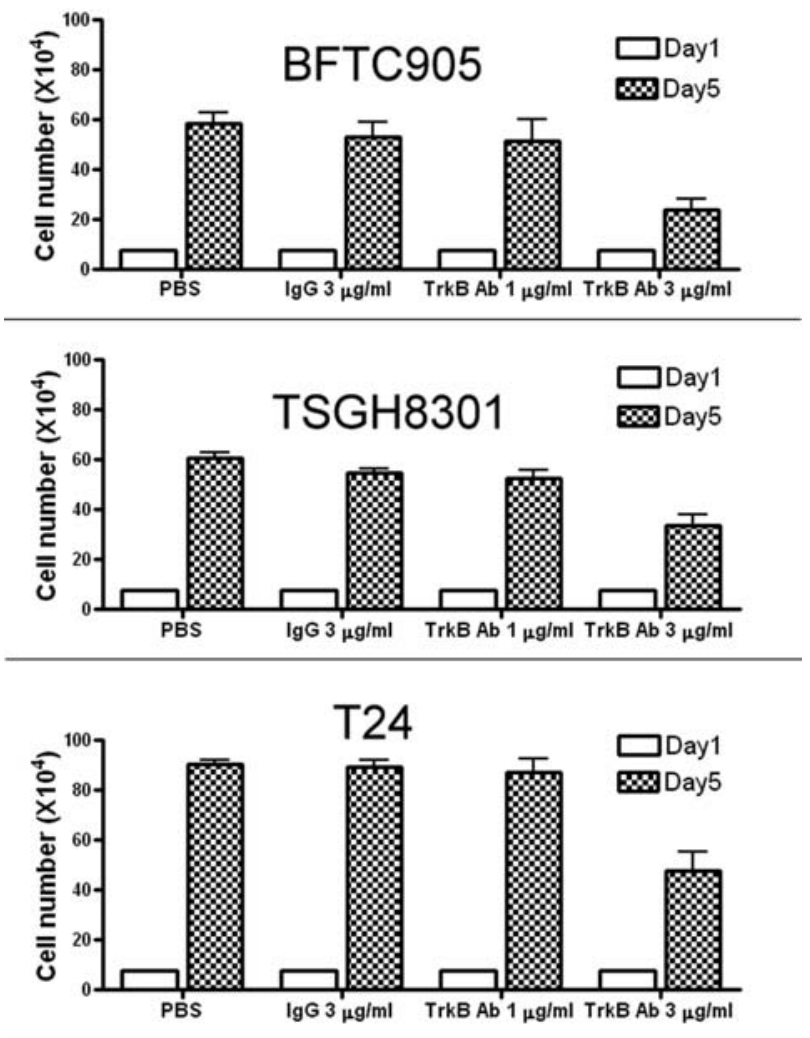

Figure 2. Anti-proliferative effect of TrkB Ab on TCC cells. Cell counts of BFTC905, TSGH8301 and T24 cells were calculated $72 \mathrm{~h}$ after PBS, IgG $3 \mu \mathrm{g} / \mathrm{ml}$, or TrkB Ab 1 and $3 \mu \mathrm{g} / \mathrm{ml}$ treatments. The differences of cell numbers between PBS and TrkB $3 \mu \mathrm{g} / \mathrm{ml}$ reached statistical significance in all TCC cell lines.

decreased significantly $24 \mathrm{~h}$ after the addition of $3 \mu \mathrm{g} / \mathrm{ml}$ TrkB Ab in TCC cells. Securin, also known as pituitary tumor-transforming gene (PTTG), plays important roles in tumorigenesis and invasiveness in various neoplasms (14). The expression of securin decreased significantly 24 and $48 \mathrm{~h}$ after the addition of $3 \mu \mathrm{g} / \mathrm{ml}$ TrkB Ab in TCC cells (except 24-h expression in TSGH8301 cells, Fig. 3E and F).

TrkB Ab inhibited migration and invasion of TCC cells. To evaluate further the effect of TrkB Ab on bladder cancer cell migration and invasion, two relatively low concentrations of TrkB $\mathrm{Ab}$ at 0.1 and $0.5 \mu \mathrm{g} / \mathrm{ml}$ were chosen for wound healing assay because these concentrations were found to be devoid of effect on the proliferation in culture medium containing $0.5 \%$ FBS. These three bladder cancer cell lines did not proliferate within $24 \mathrm{~h}$ in this starved condition (results not shown). The time-dependent changes of wound healing are shown in Fig. 4A. Narrowing and even disappearance of wounds were observed $24 \mathrm{~h}$ after human IgG treatment. Delayed healings were observed after $0.5 \mu \mathrm{g} / \mathrm{ml}$ TrkB Ab treatment, exerting the greatest inhibitory effects on migration, especially for BFTC905 and TSGH8301 cells. In addition, $0.5 \mu \mathrm{g} / \mathrm{ml}$ TrkB Ab significantly inhibited the invasive ability of BFTC905 cells in Matrigel assay (Fig. 4B). Although trends of invasive suppression for TSGH8301 and T24 cells were observed after TrkB Ab treatment, the difference, when compared to $\mathrm{IgG}$ treatment, did not reach statistical significance. 
A

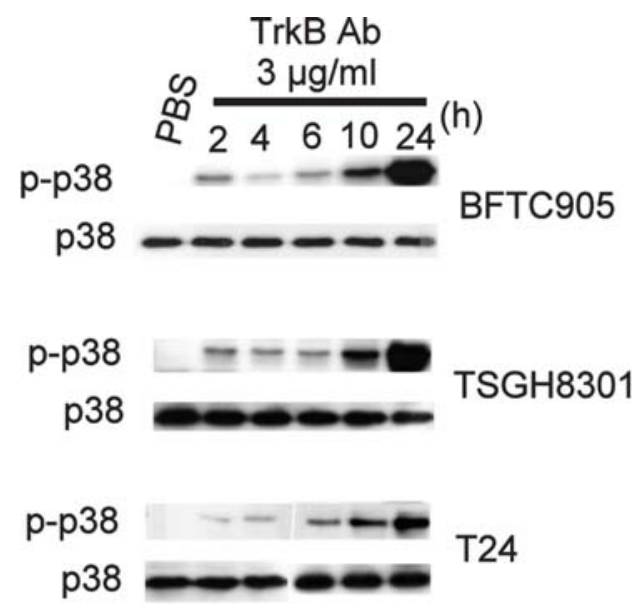

C

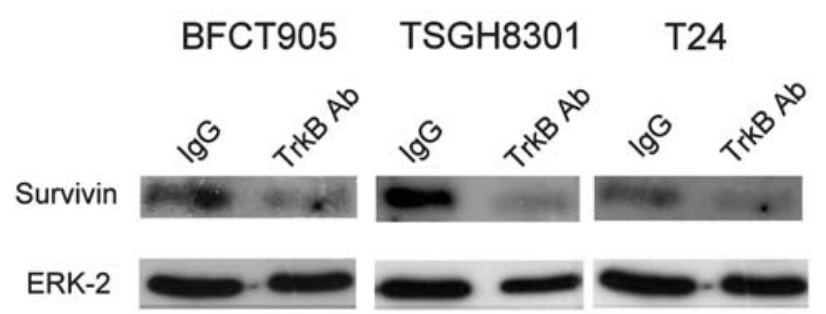

B

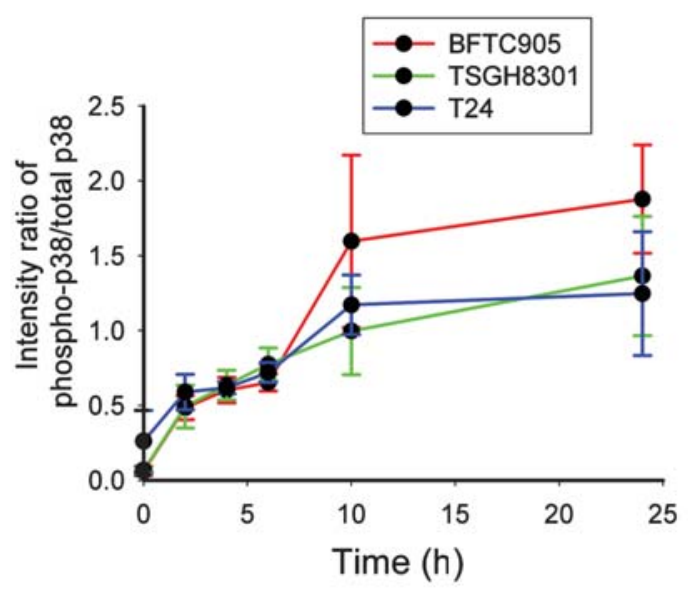

D

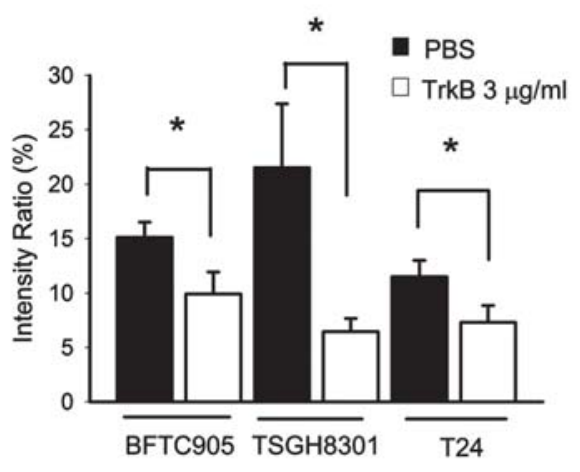

E

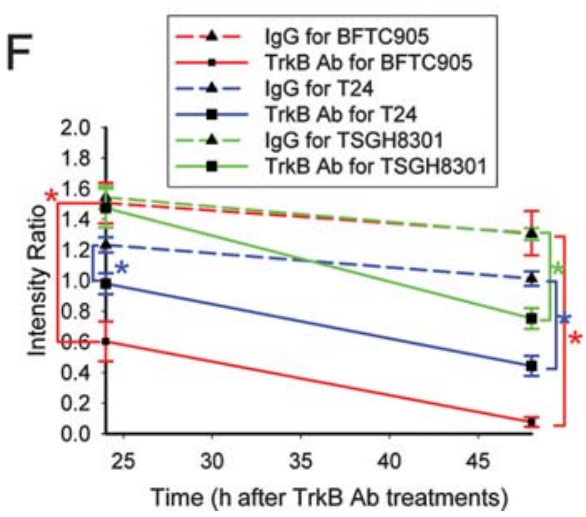

Figure 3. Changes of phospho-p38, survivin and securin levels in TCC cells after TrkB Ab treatment. (A and B) Time-dependent expression of phospho-p38 MAPK was detected by Western blots after $3 \mu \mathrm{g} / \mathrm{ml}$ TrkB Ab treatment for $24 \mathrm{~h}$. The changes of protein expression were assessed by intensity ratio derived from dividing the intensity of phospho-p38 to that of total p38. Significant increase of phospho-p38 expression induced by TrkB Ab was observed $2 \mathrm{~h}$ in BFTC905 and TSGH8301 cells, and $10 \mathrm{~h}$ in T24 cells after treatment. (C and D) Expression of survivin was detected by Western blots $24 \mathrm{~h}$ after $3 \mu \mathrm{g} / \mathrm{ml}$ $\operatorname{TrkB} \mathrm{Ab}$ treatment. The percentage changes of protein expression were presented by intensity ratio derived from dividing the intensity of survivin to that of ERK-2. Triple samples were collected from each cell lines and each treatment. The levels of survivin in 3 TCC cell lines were reduced by $3 \mu \mathrm{g} / \mathrm{ml}$ TrkB Ab treatment. (E and F) Expression of securin was detected by Western blots 24 and $48 \mathrm{~h}$ after $3 \mu \mathrm{g} / \mathrm{ml} \mathrm{TrkB} \mathrm{Ab}$ treatment. The percentage changes of protein expression were presented by intensity ratio derived from dividing the intensity of securin to that of actin. Triple samples were collected from each cell line and each treatment. Reduced expression of securin in 3 TCC cell lines reached statistical significance $48 \mathrm{~h}$ after TrkB administration.

TrkB Ab increased E-cadherin expression, inhibited phosphorylation of $P L C \gamma$, and decreased MMP-9 activity in BFTC905 cells. Epithelial-to-mesenchymal transition (EMT) through loss of E-cadherin mediates migration of TCC cells and is associated with poor outcome (15). Fig. 5A shows the changes of E-cadherin in three cell lines $24 \mathrm{~h}$ after $0.5 \mu \mathrm{g} / \mathrm{ml}$ TrkB Ab treatments. Increased E-cadherin expression was observed in BFTC905 cells compared to IgG treatment. E-cadherin was not expressed in T24 cells after IgG and TrkB
Ab treatments. Weak E-cadherin expression in TSGH8301 cells was noted, but was not changed after TrkB Ab treatment.

TrkB has been demonstrated to mediate neuronal migration via PLC $\gamma(16)$, which has also been found to play a role in the migration and invasion of cancer cells after growth factor (e.g., epidermal growth factor) stimulation $(17,18)$. Due to significant inhibition of invasive activity in BFTC905 cells after TrkB Ab treatment, the changes of phospho-PLC $\gamma$ were measured in BFTC905 cells by Western blotting 
A

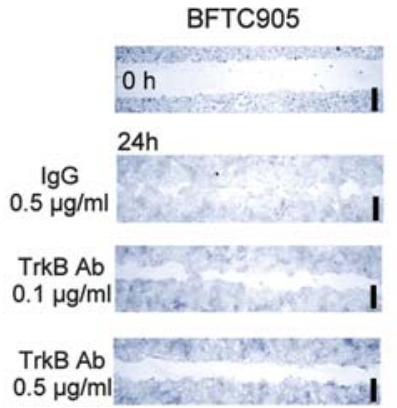

TSGH8301

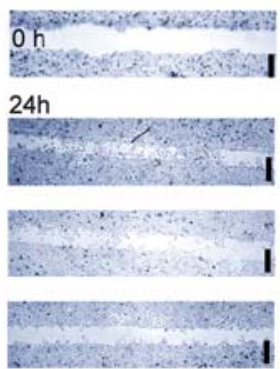

$\mathrm{T} 24$

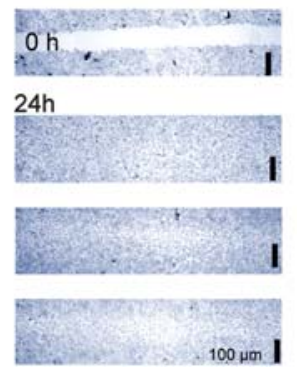

B

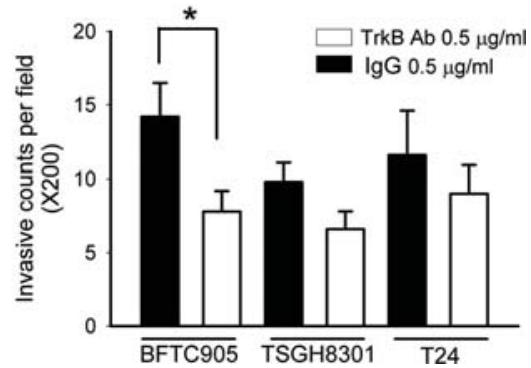

Figure 4. Inhibitory effects on migration and invasion in TCC cells. (A) Wound healing assay was used for the migratory activity of TCC cell lines. Inhibition of migration in BFTC905 cells by 0.1 and $0.5 \mu \mathrm{g} / \mathrm{ml}$ TrkB Ab was examined $24 \mathrm{~h}$ after treatment. The experiments were repeated three times with similar results. (B) Cancer cell invasion was detected by Matrigel assay after $0.5 \mu \mathrm{g} / \mathrm{ml}$ of IgG or TrkB Ab. After $48 \mathrm{~h}$ incubation, invading cells on the bottom surface of the membrane were counted under the microscope (x200). Inhibition of invasion after TrkB Ab reached statistical significance only in BFTC905 cells.

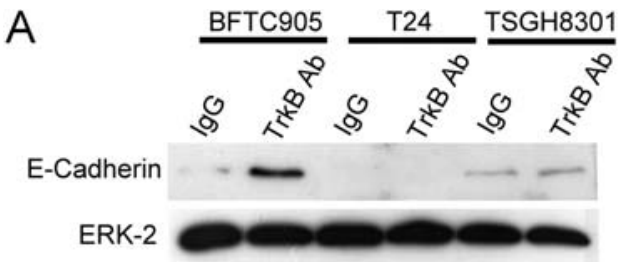

B

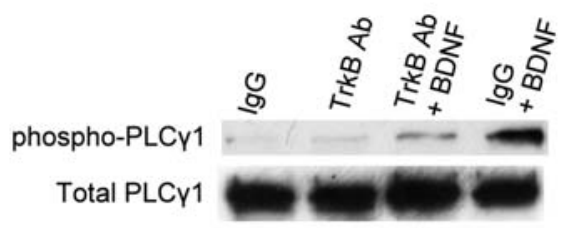

C

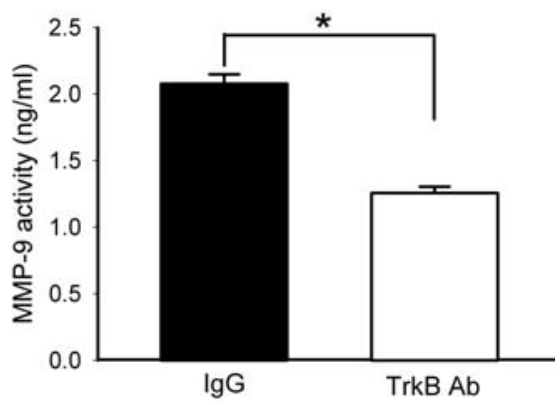

Figure 5. Effects of TrkB Ab on migration/invasion-related proteins in TCC cells. (A) Expression of E-cadherin in TCC cells was detected by Western blotting after $0.5 \mu \mathrm{g} / \mathrm{ml}$ of IgG or TrkB Ab treatments. (B) Phospho-PLC $\gamma 1$ expression in BFTC905 cells was detected by Western blotting after $10 \mathrm{nM}$ rhBDNF stimulation or pre-treatment with $0.5 \mu \mathrm{g} / \mathrm{ml}$ of TrkB Ab for $24 \mathrm{~h}$. (C) Extracellular MMP-9 activity of BFTC905 cells was detected by ELISA $24 \mathrm{~h}$ after $0.5 \mu \mathrm{g} / \mathrm{ml}$ TrkB Ab treatment.

(Fig. 5B). Addition of $10 \mathrm{nM}$ rhBDNF for $10 \mathrm{~min}$ increased the phosphorylation of PLC $\gamma 1$. IgG $(0.5 \mu \mathrm{g} / \mathrm{ml})$ or TrkB Ab $(0.5 \mu \mathrm{g} / \mathrm{ml})$ alone was without effect on the phospho-PLC $\gamma 1$ level. Pre-treatment with $0.5 \mu \mathrm{g} / \mathrm{ml}$ of human $\mathrm{IgG}$ did not alter the response elicited by $10 \mathrm{nM}$ rhBDNF. In contrast, pre-treatment with $\operatorname{TrkB} \mathrm{Ab}(0.5 \mu \mathrm{g} / \mathrm{ml})$ for $24 \mathrm{~h}$ almost completely inhibited phospho-PLC $\gamma 1$ expression $10 \mathrm{~min}$ after the addition of $10 \mathrm{nM}$ rhBDNF.
The level of MMP-9 is higher in high grade and more invasive type of urothelial carcinoma (19). Thus, we examined the MMP-9 activity in culture medium of BFCT905 cells by ELISA assay. MMP-9 activity was significantly inhibited by $40 \%$ after TrkB Ab treatment for $24 \mathrm{~h}(2.08 \pm 0.07 \mathrm{ng} / \mathrm{ml}$ vs. $1.26 \pm 0.05 \mathrm{ng} / \mathrm{ml}, \mathrm{IgG}$ vs. TrkB treatment, respectively).

\section{Discussion}

BDNF and TrkB have been found in various cancer tissues, e.g., prostate cancer (20), and hepatocellular carcinoma (HCC) (21). However, there are only few reports investigating TrkB blockade as a new target therapy. Indolocarbazole alkaloid K252a was widely used as the Trk family inhibitor in neuroscience and cancer studies $(22,23)$. However, K252a is also a potent inhibitor of protein kinases, e.g, protein kinase C (PKC) (24), and myosin light chain kinase (MLCK) (25). It also inhibits the phosphorylation of c-met protein (MET) (26). Moreover, PKC (27), MLCK (28) and MET (29) also play important roles in cancer progression. Thus, the therapeutic effects of K252a on cancers may result from acting on multiple targets. RNA interference of TrkB is a specific method for TrkB inhibition $(7,30)$, but the clinical application of systemic siRNA administration has just begun (phase I trial) (31). Neutralizing antibodies targeting on RTK (receptor tyrosine kinase), such as trastuzumab, have been widely used in cancer patients (32). Therefore, we used TrkB antibody for its blocking effect in TCC cells.

The wild-type TrkB protein contains five domains. A recent structure-activity study demonstrated that tyrosine kinase activity of TrkB plays critical functions for antianoikis, tumorigenesis and metastasis (33). Deletion of LRM (leucine-rich motif) or Ig-2 (IgG-like domain 2) eliminated TrkB functions, indicating that they play important roles in mediating BDNF response. In our study, the sc-8316 antibody binding to the extracellular domain of TrkB is against amino acids 160-340, which covers the extracellular Ig-1 and Ig-2 domain. Consequently, it will inhibit the binding of BDNF to the extracellular domain of TrkB and block the downstream signaling pathways. This may explain why sc-8316 antibody inhibited proliferation and migration/invasion of TCC cells in vitro, as well as blocked the phosphorylation 
of TrkB and PLC $\gamma 1$ despite rhBDNF stimulation in our current and previous studies (8). The TrkB inhibition also induced p 38 phorphorylation, suppressed survivin and securin expression, and finally caused apoptosis of TCC cells in our experiments. As far as we know, our results are the first report to elucidate the signaling mechanism among p38, survivin, securin and TrkB in cancers. Cytotoxicity and apoptotic effect have been observed after survivn siRNA treatment in T24 cells $(34,35)$. Survivin inhibition may partly explain the TrkB Ab-induced apoptosis in TCC cells. Overexpressed securin in glioma specimens is associated with an unfavorable consequence (36). Our study also demonstrated the expression of securin in TCC cells, and the inhibition of securin expression by TrkB blockade. The detailed signalings among survivin, securin and TrkB should be investigated in the future.

We also studied the effect of TrkB Ab on the migration and invasion in TCC cells. Migration of BFTC905 and TSGH8301 cells was delayed when TrkB receptor was blocked with concentration of TrkB Ab that was without anti-proliferative effect but weak inhibitory effect was observed in T24 cells. The discrepancy between 3 TCC cell lines might have resulted from the E-cadherin expression. BDNF activation of TrkB receptors mediated the migration and invasion of head and neck squamous cell carcinoma cells via EMT promotion, which upregulated twist and downregulated E-cadherin (37). No dynamic twist changes following TrkB treatment in 3 TCC cell lines were observed (results not shown). Upregulated E-cadherin in BFTC905 cells could explain the migration and invasion inhibition after TrkB blockade. Our study is consistent with a previous report which demonstrated the absence of E-cadherin protein and mRNA level in T24 cells (38). It may explain the weak inhibition of migration and the absence of inhibition on invasion in T24 cells after TrkB blockade. Furthermore, it has been shown that PLC $\gamma 1$ mediates neuronal migration after TrkB activation (17) and cancer cell migration/invasion after EGF stimulation (18). Thus, we examined the phosphorylation of PLC $\gamma 1$ in BFTC905 cells after rhBDNF stimulation. Phospho-PLC $\gamma 1$ activation was evident 5 min after rhBDNF stimulation and lasted for $30 \mathrm{~min}$ (results not shown). The activation was inhibited when cells were pre-treated with TrkB Ab for $24 \mathrm{~h}$. Thus, PLC $\gamma 1$ phosphorylation may also play important roles in the migratory and invasive effects of BDNF-TrkB interaction in TCC cells. BDNF has been found to promote MMP-9 secretion in human multiple myeloma cells (39). Decrease of extracellular MMP-9 activity in BFTC905 cells after TrkB Ab treatment results in poor degradation of the matrigel, suggesting that $\operatorname{TrkB} A b$ elicited inhibitory effect on invasion.

In conclusion, TrkB blockade by TrkB Ab elicited cytotoxicity, induced apoptosis, and suppressed migration/ invasion of TCC cells in vitro. Agents aimed at blocking TrkB may have potential as a new therapy for bladder cancer.

\section{Acknowledgements}

This study was partially supported by grant-in-aid from Tzu Chi University (THC) and Tzu Chi General Hospital (YTH), Hualien 970, Taiwan, and a grant from NSC (NSC-97-2314B-303-016, YTH), Taiwan.

\section{References}

1. Heumann R: Neurotrophin signalling. Curr Opin Neurobiol 4: 668-679, 1994.

2. Lamballe F, Klein R and Barbacid M: The trk family of oncogenes and neurotrophin receptors. Princess Takamatsu Symp 22: 153-170, 1992.

3. Coulier F, Martin-Zanca D, Ernst M and Barbacid M: Mechanism of activation of the human trk oncogene. Mol Cell Biol 9: 15-23, 1989.

4. Nakagawara A: Trk receptor tyrosine kinases: A bridge between cancer and neural development. Cancer Lett 169: 107-114, 2001.

5. Scala S, Wosikowski K, Giannakakou P, et al: Brain-derived neurotrophic factor protects neuroblastoma cells from vinblastine toxicity. Cancer Res 56: 3737-3742, 1996.

6. Tanaka T, Hiyama E, Sugimoto T, Sawada T, Tanabe M and Ida N: Trk A gene expression in neuroblastoma. The clinical significance of an immunohistochemical study. Cancer 76: 1086-1095, 1995

7. Yu X, Liu L, Cai B, He Y and Wan X: Suppression of anoikis by the neurotrophic receptor trkB in human ovarian cancer. Cancer Sci 99: 543-552, 2008.

8. Huang YT, Pei Chun Lai PC, Wu CC, Hsu SH, Cheng CC, Lan YF and Chiu TH: BDNF mediated TrkB activation is a survival signal for transitional cell carcinoma cells. Int J Oncol 36: 1469-1476, 2010.

9. Tzeng CC, Liu HS, Li C, Jin YT, Chen RM, Yang WH and Lin JS: Characterization of two urothelium cancer cell lines derived from a blackfoot disease endemic area in Taiwan. Anticancer Res 16: 1797-1804, 1996.

10. Yeh MY, Yu DS, Chen SC, Lin MS, Chang SY, Ma CP and Han SH: Establishment and characterization of a human urinary bladder carcinoma cell line (TSGH-8301). J Surg Oncol 37: 177-184, 1988.

11. Olson JM and Hallahan AR: P38 map kinase: A convergence point in cancer therapy. Trends Mol Med 10: 125-129, 2004.

12. Akhtar M, Gallagher L and Rohan S: Survivin: Role in diagnosis, prognosis, and treatment of bladder cancer. Adv Anat Pathol 13: 122-126, 2006.

13. Margulis V, Lotan Y and Shariat SF: Survivin: A promising biomarker for detection and prognosis of bladder cancer. World J Urol 26: 59-65, 2008

14. Salehi F, Kovacs K, Scheithauer BW, Lloyd RV and Cusimano M: Pituitary tumor-transforming gene in endocrine and other neoplasms: a review and update. Endocr Relat Cancer 15: 721-743, 2008.

15. McConkey DJ, Choi W, Marquis L, et al: Role of epithelialto-mesenchymal transition (EMT) in drug sensitivity and metastasis in bladder cancer. Cancer Metastasis Rev 28: 335-344, 2009.

16. Medina DL, Sciarretta C, Calella AM, Von Bohlen Und Halbach O, Unsicker K and Minichiello L: TrkB regulates neocortex formation through the Shc/PLCgamma-mediated control of neuronal migration. EMBO J 23: 3803-3814, 2004.

17. Nozawa H, Howell G, Suzuki S, et al: Combined inhibition of PLC $\gamma 1$ and c-Src abrogates epidermal growth factor receptormediated head and neck squamous cell carcinoma invasion. Clin Cancer Res 14: 4336-4344, 2008.

18. Dittmar T, Husemann A, Schewe Y, Nofer JR, Niggemann B, Zanker KS and Brandt BH: Induction of cancer cell migration by epidermal growth factor is initiated by specific phosphorylation of tyrosine 1248 of c-erbB-2 receptor via EGFR. FASEB J 16: 1823-1825, 2002.

19. Donmez G, Sullu Y, Baris S, Yildiz L, Aydin O, Karagoz F and Kandemir B: Vascular endothelial growth factor (VEGF), matrix metalloproteinase-9 (MMP-9), and thrombospondin-1 (TSP-1) expression in urothelial carcinomas. Pathol Res Pract 205: 854-857, 2009.

20. Montano $X$ and Djamgoz MB: Epidermal growth factor, neurotrophins and the metastatic cascade in prostate cancer. FEBS Lett 571: 1-8, 2004

21. Yang ZF, Ho DW, Lam CT, et al: Identification of brainderived neurotrophic factor as a novel functional protein in hepatocellular carcinoma. Cancer Res 65: 219-225, 2005.

22. Nye SH, Squinto SP, Glass DJ, et al: K-252a and staurosporine selectively block autophosphorylation of neurotrophin receptors and neurotrophin-mediated responses. Mol Biol Cell 3: 677-686, 1992. 
23. Takai N, Ueda T, Nishida M, Nasu K and Narahara H: K252a is highly effective in suppressing the growth of human endometrial cancer cells, but has little effect on normal human endometrial epithelial cells. Oncol Rep 19: 749-753, 2008.

24. Kase H, Iwahashi K and Matsuda Y: K-252a, a potent inhibitor of protein kinase $\mathrm{c}$ from microbial origin. J Antibiot (Tokyo) 39: 1059-1065, 1986.

25. Lazarovici P, Rasouly D, Friedman L, Tabekman R, Ovadia H and Matsuda Y: K252a and staurosporine microbial alkaloid toxins as prototype of neurotropic drugs. Adv Exp Med Biol 391: 367-377, 1996.

26. Morotti A, Mila S, Accornero P, Tagliabue E and Ponzetto C: K252a inhibits the oncogenic properties of Met, the HGF receptor. Oncogene 21: 4885-4893, 2002.

27. Kong C, Zhu Y, Liu D, Yu M, Li S, Li Z, Sun Z and Liu G: Role of protein kinase C-alpha in superficial bladder carcinoma recurrence. Urology 65: 1228-1232, 2005.

28. Zhou X, Liu Y, You J, Zhang H, Zhang X and Ye L: Myosin light-chain kinase contributes to the proliferation and migration of breast cancer cells through cross-talk with activated ERK1/2. Cancer Lett 270: 312-327, 2008.

29. Comperat E, Roupret M, Chartier-Kastler E, et al: Prognostic value of met, ron and histoprognostic factors for urothelial carcinoma in the upper urinary tract. J Urol 179: 868-872, 2008.

30. Yu XH, Yang YX, Cai B, Yan Q, He YY and Wan XP: [anoikis-suppression and invasion induced by tyrosine kinase receptor B in OVCAR3 ovarian cancer cells]. Zhonghua Fu Chan Ke Za Zhi 43: 695-699, 2008.

31. Davis ME, Zuckerman JE, Choi CH, et al: Evidence of RNAi in humans from systemically administered siRNA via targeted nanoparticles. Nature (In press).
32. Eiermann W: Trastuzumab combined with chemotherapy for the treatment of HER2-positive metastatic breast cancer: Pivotal trial data. Ann Oncol 12 (Suppl. 1): S57-S62, 2001.

33. Geiger TR and Peeper DS: Critical role for trkb kinase function in anoikis suppression, tumorigenesis, and metastasis. Cancer Res 67: 6221-6229, 2007.

$34 \mathrm{Ku}$ JH, Seo SY, Kwak C and Kim HH: Cytotoxicity and apoptosis by survivin small interfering RNA in bladder cancer cells. BJU Int (In press).

35. Chao JI, Su WC and Liu HF: Baicalein induces cancer cell death and proliferation retardation by the inhibition of CD2 kinase and survivin associated with opposite role of p38 mitogen-activated protein kinase and akt. Mol Cancer Ther 6: 3039-3048, 2007

36. Genkai N, Homma J, Sano M, Tanaka R and Yamanaka R: Increased expression of pituitary tumor-transforming gene (PTTG)-1 is correlated with poor prognosis in glioma patients. Oncol Rep 15: 1569-1574, 2006.

37. Kupferman ME, Jiffar T, El-Naggar A, et al: TrkB induces EMT and has a key role in invasion of head and neck squamous cell carcinoma. Oncogene (In press).

38. Wakatsuki S, Watanabe R, Saito K, Saito T, Katagiri A, Sato S and Tomita Y: Loss of human E-cadherin (ECD) correlated with invasiveness of transitional cell cancer in the renal pelvis, ureter and urinary bladder. Cancer Lett 103: 11-17, 1996.

39. Zhang L, Hu Y, Sun CY, Huang J and Chu ZB: [brain-derived neurotrophic factor promotes the secretion of MMP-9 in human myeloma cell through modulation of nucleus factor-kappaB]. Zhonghua Xue Ye Xue Za Zhi 29: 243-246, 2008. 